А. В. Полховский, С. А. Прохорчик, С. В. Шетько, Е. В. Ручкина Белорусский государственный технологический университет

\title{
РАЗРАБОТКА КОНСТРУКЦИИ ОБЛЕГЧЕННЫХ СПОРТИВНО-БЕГОВЫХ ПЛАСТИКОВЫХ ЛЫЖ
}

Статья посвящена анализу результатов разработки конструкции и изготовления облегченных спортивно-беговых пластиковых лыж. Приведены наиболее часто применяемые при изготовлении облегченных лыж материалы. К ним относятся материалы на основе сотового заполнителя и вспененные материалы (полиуретан). Описаны клинья экспериментальных образцов облегченных спортивно-беговых пластиковых лыж, которые были изготовлены в филиале «Телеханы» государственного предприятия «Беларусьторг», а именно клинья из материала на основе сотового заполнителя (в качестве сотового заполнителя был использован склеенный пакет из пяти листов пятислойного гофрокартона), клин из вспененных материалов (пенополиуретан), клин из модельного материала, полученный методом 3D-печати, и клин из древесины низкой плотности.

Полученные экспериментальные образцы облегченных лыж были подвергнуты испытаниям по определению основных эксплуатационных показателей качества, а именно массы, величины стрелы прогиба, жесткости средней части, индекса жесткости по Фишеру, высоты и длины остаточного прогиба, разрушающей нагрузки, показателя усталости при циклическом нагружении, жесткости передней и задней части.

На основании проведенных испытаний определены наиболее перспективные материалы для изготовления среднего клина облегченных спортивно-беговых пластиковых лыж. Лучшие результаты при испытаниях были выявлены у древесины низкой плотности.

Ключевые слова: лыжи, гофрокартон, пенополиуретан, 3D-печать, масса, жесткость, прочность.

Для цитирования: Полховский А. В., Прохорчик С. А., Шетько С. В., Ручкина Е. В. Разработка конструкции облегченных спортивно-беговых пластиковых лыж // Труды БГТУ. Сер. 1, Лесное хоз-во, природопользование и перераб. возобновляемых ресурсов. 2021. № 2 (246). C. 250-259.

\section{A. V. Polkhovsky, S. A. Prokhorchik, S. V. Shet'ko, E. V. Ruchkina Belarusian State Technological University \\ DESIGN DEVELOPMENT OF LIGHTWEIGHT SPORTS AND RUNNING PLASTICK SKI}

The article is devoted to the analysis of the results of work on the design and manufacture of lightweight sports and cross-country plastic skis. The article lists the materials most often used in the manufacture of lightweight skis. These include honeycomb-based materials and foams (polyurethane). The wedges of experimental samples of lightweight sports and cross-country plastic skis, which were manufactured by the Telekhany branch of the state enterprise Belarustorg, are described, namely, wedges made of a material based on honeycomb filler (A glued package of five sheets of five-layer corrugated board was used as a honeycomb core), a wedge made of foam materials (polyurethane foam), 3D printed model wedge and low density wood wedge.

The obtained experimental samples of lightweight skis were tested to determine the main performance indicators of quality, namely, mass, deflection, stiffness of the middle section, Fischer stiffness index, height and length of residual deflection, breaking load, fatigue index under cyclic loading, stiffness front and back.

Based on the tests carried out, the most promising materials for the manufacture of the middle wedge of lightweight sports and cross-country plastic skis were determined. The best test results were found in low density wood. The article is devoted to the analysis of the results of work on the design and manufacture of lightweight sports and cross-country plastic skis.

Key words: skis, corrugated board, polyurethane foam, 3D printing, weight, stiffness, strength.

For citation: Polkhovsky A. V., Prokhorchik S. A., Shet'ko S. V., Ruchkina E. V. Design development of lightweight sports and running plastick ski. Proceessings of BSTU, issue 1, Forestry. Nature Management. Processing of Renewable Resources, 2021, no. 2 (246), pp. 250-259 (In Russian). 
Введение. В современных конструкциях лыж применяются различные сочетания материалов (многие виды пластика, древесины, композитных материалов, сплавов). Все производимые лыжи имеют общие элементы в конструкции, такие как скользящий слой, армирующий слой, склеивающий слой, верхний (декоративный) слой, средний клин. Одним из главных требований, предъявляемых к лыжам, является величина их массы. При прочих равных условиях основное влияние на массу оказывает средний клин. Именно различия в материалах и конструкциях среднего клина оказывают существенное влияние на эксплуатационные показатели качества спортивно-беговых пластиковых лыж.

Лыжи используют как любители, так и профессионалы. Лыжи для начинающих обладают доступной ценой, низким уровнем жесткости и более высокой массой, что обусловлено применением в их конструкции более дешевых материалов. К лыжам для профессиональных спортсменов предъявляются более высокие требования, применяются самые современные инновационные материалы и технологии, в связи с чем стоимость лыж для спортсменов очень высокая. В связи с чем разработка подобных лыж является актуальной задачей.

Объектом исследования являются лыжи, предметом - материалы, используемые в изготовлении среднего клина облегченных лыж, эксплуатационные показатели качества.

Целью данной работы является подбор материалов для изготовления среднего клина с целью снижения массы до значения, не превышающего 550 г и повышения эксплуатационных физикомеханических показателей.

Для достижения поставленной цели были решены следующие задачи: проведен анализ материалов, применяемых для изготовления среднего клина облегченных лыж, на основании анализа выбрано несколько материалов, из выбранных материалов изготовлены экспериментальные образцы лыж, полученные образцы лыж подвергнуты испытаниям по определению эксплуатационных показателей качества.

Основная часть. Для исследований было рассмотрено несколько вариантов материалов и конструкций клиньев, применяемых при изготовлении облегченных спортивно-беговых лыж. А именно, клин из материалов на основе сотового заполнителя, из вспененных материалов, из модельного материала, полученный методом $3 \mathrm{~d}$-печати, и клин из древесины низкой плотности. Далее рассмотрим более подробно вышеперечисленные материалы.

Средний клин из материалов на основе сотового заполнителя. Сотовая структура представляет собой тип ячеистых материалов с регулярными и периодически повторяющимися наборами ячеек различной формы, образованных между тонкими вертикальными стенками. Ячейки в основном имеют шестиугольную форму или расположены в виде столбцов. Для изготовления сот могут применятся различные виды материалов (алюминий, нержавеющая сталь, арамид, кевлар, термопластик, картон). Жесткость сотовых конструкций позволяет использовать меньше материала и снизить массу. Жесткость увеличивается экспоненциально по сравнению с однослойным материалом. Использование сотовых клиньев создает резкое увеличение жесткости при очень небольшом увеличении массы лыжи $[1,2,3]$.

Алюминиевые соты - инновационный материал, разработанный в 20-м веке, для облегчения конструкций с сохранением необходимых характеристик. Преимущество алюминиевых сот - небольшая масса, наилучшая устойчивость к сжатию и растяжению, пажаростойкость, коррозионная стойкость и многое другое. Толщина слоя алюминия составляет от 3 до 300 мкм, диаметр отверстия - от 6 до 19 мм, плотность ячеистых сот (в зависимости от толщины фольги и

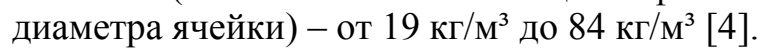

Применение в конструкции лыж алюминиевых сот было произведено еще в 80-х гг. на Таллинской экспериментальной лыжной фабрике «Динамо», прочность которых оказалась в пять раз выше, чем у сотопласта. У таких лыж не требуется упрочнять древесиной боковые поверхности, что позволяет выпускать более легкие лыжи (масса лыж длиной 205 см составила 450 г). Испытания показали, что физико-механические показатели лыж, изготовленных с применением алюминиевых сот, выше, чем у лыж из сотопласта [5].

Apамидные соты Noтех. Являются чрезвычайно легким, высокопрочным, неметаллическим продуктом, изготовленным из арамидного волокна, пропитанного фенольной термостойкой смолой. Арамид - химическое волокно, отличающееся высокими показаниями прочности, стойкостью к высоким температурам и упругостью. Также имеет повышенную стойкость к воздействию различных химических реагентов. Используется как добавка в композитные материалы и в производстве высокопрочных тканей. Название «арамид» волокна получили от английской аббревиатуры слов «ароматический полиамид». Высокая прочность материала обеспечивается тем, что молекулы этого вещества имеют одинаковую направленность. Современный рынок предлагает три основных типа арамидных волокон: пара-арамиды (тварон, кевлар, CВM, терлон); мета-арамиды (номекс, арселон); сополимеры арамидов (кермель) $[6,7,8]$. 
Термопластик. Ячеистые клинья из термопластика легкие и легко поддаются переработке. Основным недостатком является сложность создания прочной связи между сотами и облицовкой. Они бывают нескольких типов:

- $A B S$, использование которого предполагает жесткую структуру, ударную вязкость, твердость поверхности, ударопрочность и размерную стабильность;

- поликарбонат обеспечивает устойчивость к ультрафиолетовому излучению, хорошее светопропускание, высокую термостойкость и самозатухающие свойства;

- полипропилен обеспечивает исключительную химическую стойкость.

Гофрокартон представляет собой многослойную конструкцию, состоящую из внутреннего слоя бумаги «флютинга», сформированного на гофроагрегате так, что бумаге придается волнистая форма, и из одного или нескольких плоских слоев картона, называемого «лайнером», приклеенных к вершинам гофров. Гофрокартон отличается от других видов картона малым весом, дешевизной и высокими физическими параметрами.

При приложении сил в направлении, перпендикулярном гофрам, гофрокартон работает как амортизирующий материал за счет малой жесткости в этом направлении волнистого слоя. При приложении сил вдоль направления гофров гофрокартон проявляет высокую плоскостную и торцевую жесткость благодаря большой жесткости в этом направлении волнистого слоя [9].

Плоские слои гофрированного картона фиксируют положение волнистых слоев, поэтому воспринимают сжимающие, растягивающие и продавливающие нагрузки [9].

Гофрокартон изготавливается из целлюлозного и макулатурного сырья, что позволяет получить различные марки по степени прочности, нагрузочным характеристикам. В зависимости от числа слоев гофрированный картон изготавливают следующих типов $[10,11,12]$ :

- Д (двухслойный), состоящий из одного плоского и одного гофрированного слоев;

- Т (трехслойный), состоящий из двух плоских и одного гофрированного слоев;

- П (пятислойный), состоящий из трех плоских (двух наружных и одного внутреннего) и двух гофрированных слоев;

- С (семислойный), состоящий из четырех плоских (двух наружных и двух внутренних) и трех гофрированных слоев.

После изучения различных видов сотовых материалов, в качестве их замены был выбран гофрокартон, который сочетает в себе такие показатели, как низкая стоимость, доступность, высокие физические параметры. Для изготовления клиньев лыж был использован пятислойный гофрокартон. Для упрочнения клиньев применялись боковые поверхности из четырехмиллиметровой березовой фанеры.

Технология изготовления клина из гофрокартона заключалась в следующем: листы картона раскраивались на заготовки необходимой конфигурации, эти заготовки склеивались между собой для получения пакета нужной толщины, далее к обеим его пластям приклеивались листы фанеры, затем из полученного пакета вырезались клинья.

Конструкция клина из гофрокартона приведена на рис. 1.

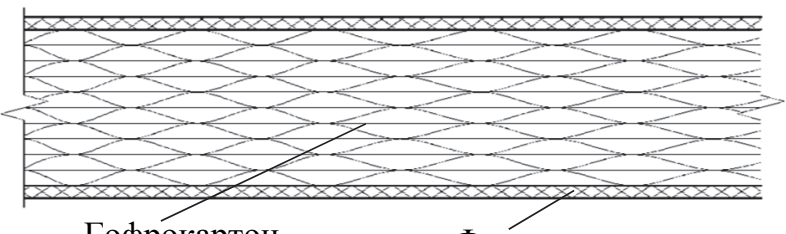

Гофрокартон

Фанера

Рис. 1. Структура среднего клина из гофрокартона

Средний клин из вспененных материалов. В качестве вспененного материала при изготовлении среднего клина использовался пенополиуретан - это синтетическое вещество ячеистой структуры из группы газонаполненных пластмасс. По сути, пенополиуретан можно охарактеризовать как разновидность пластмассы.

Основным сырьем, используемым для получения пенополиуретана, являются ди- и триизоцианаты и полиолы. Другие технологические добавки вводятся для изменения свойств полимера.

Свойства пенополиуретана можно классифицировать на основе структуры пены. Пена имеет два типа структуры [13]: с открытыми порами и закрытыми порами.

Пена с открытыми порами такая же мягкая, как подушка. Ячейки стенок или поверхности пузырьков разрушаются и наполняются воздухом, который заполняет все пространства в материале. Это делает пену мягкой или слабой, и по ощущениям она напоминает мягкую игрушечную резиновую грушу. Изоляционный показатель этой пены связан с показателем изоляции воздуха внутри матрицы разрушенных ячеек. Плотность пенопласта с открытыми порами составляет около 8-12 кг/ $\mathrm{M}^{3}$ [13].

Плотность пены с закрытыми порами зависит от твердости. Нормальный, с закрытыми порами, или флотационный, полиуретан имеет плотность где-то между 32 и 48 кг/м ${ }^{3}$. Он достаточно силен, чтобы противостоять серьезным искажениям. Большинство ячеек или пузырьков в пене не разбиты, и они напоминают футбольные 
мячи, которые сложены вместе в компактную конфигурацию. Это делает пену прочной или жесткой, потому что пузырьки достаточно стабильны, чтобы выдерживать большое давление, например надутые шины, которые выдерживают вес автомобиля. Ячейки заполнены специальным газом, отобранным для того, чтобы сделать показатель изоляции пены как можно выше [13].

Преимущества пенополиуретанов с закрытыми порами по сравнению с пенополиуретанами с открытыми порами состоят в том, что они имеют более высокую прочность и большую устойчивость к утечке воздуха или водяного пара. Недостаток пенопластов с закрытыми порами состоит в том, что из-за более высокой плотности их потребность в материале больше, и они не экономичны.

Поэтому для изготовления клиньев была использована пена с закрытыми порами. Технология изготовления клиньев из пенополиуретана заключается в заливке пены в форму. Для придания клину дополнительной прочности в конструкции клина были использованы боковые поверхности из древесины осины.

Конструкция клина из пенополиуретана приведена на рис. 2

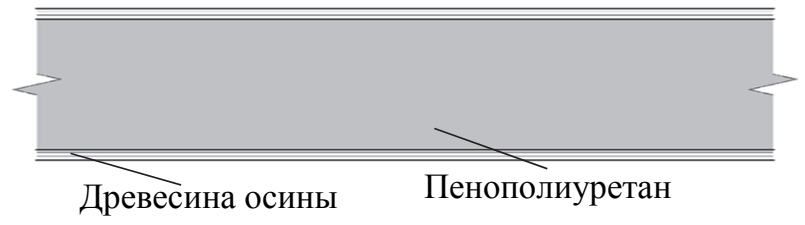

Рис. 2. Структура среднего клина из пенополиуретана

Средний клин, полученный методом 3d-nечати. Принцип построения среднего клина заключается в послойном выращивании изделия из предварительно расплавленной пластиковой нити. 3D-модель клина в формате STL передается в программное обеспечение 3Dпринтера. Программа автоматически (или опе- ратор вручную) располагает модель в виртуальном пространстве рабочей камеры. Затем программа автоматически генерирует элементы вспомогательных конструкций (из специального материала поддержки) и проводит расчет количества расходных материалов, a также времени выращивания прототипа. Перед запуском процесса печати модель автоматически разделяется на горизонтальные слои и производится расчет путей перемещения печатающей головки.

Затем запускается процесс непосредственной 3D-печати: нагревающая головка с фильерами (экструдер) расплавляет тонкую пластиковую нить (леску) и послойно укладывает ее согласно данным математической 3D-модели.

После завершения процесса построения изделия вспомогательные конструкции удаляются (вручную или растворяются в специальном растворе). Готовое изделие может быть использовано в напечатанном виде или подвергнуто любому способу пост-обработки.

Средний клин из древесины низкой плотноcmu (около $150 \kappa 2 / \mathrm{m}^{3}$ ). Технология изготовления клина из древесины низкой плотности аналогична технологии изготовления спортивно-беговых пластиковых лыж с клином из древесины осины, которая применяется в филиале «Телеханы» государственного предприятия «Беларусьторг» (калибровка заготовок; оптимизация заготовок; сращивание заготовок по длине; формирование поперечного сечения; склеивание заготовок по ширине; раскрой заготовок вдоль; создание базовой поверхности; торцовка заготовок; фрезерование по профилю, придание клину окончательной формы).

Таким образом, в условиях филиала «Телеханы» была изготовлена экспериментальная партия лыж с клиньями из гофрокартона, пенополиуретана, древесины низкой плотности и модельного материала методом 3D-печати.

Результаты определения массы, положения центра тяжести и стрелы прогиба приведены в табл. 1.

Таблица 1

Результаты определения массы, положения центра тяжести и стрелы прогиба

\begin{tabular}{|c|c|c|c|c|c|}
\hline \multirow{2}{*}{$\begin{array}{c}\text { Материал среднего } \\
\text { клина и характер } \\
\text { армирования }\end{array}$} & $\begin{array}{c}\text { Длина лыжи / } \\
\text { высота колодки, } \\
\text { мм }\end{array}$ & № образца & Mасса, г & $\begin{array}{c}\text { Положение центра } \\
\text { тяжести, мм }\end{array}$ & $\begin{array}{c}\text { Стрела прогиба, } \\
\text { мм }\end{array}$ \\
\hline \multirow{2}{*}{$\begin{array}{c}\text { Гофрокартон } \\
\text { (4 слоя СВ*) }\end{array}$} & \multirow{2}{*}{$1900 / 21,5$} & 1.1 & 687 & 901 & 27,8 \\
\hline & & 1.2 & 685 & 901 & 28,5 \\
\cline { 3 - 6 } & & 1.3 & 581 & 904 & 30 \\
\hline Гофрокартон & $(2$ слоя СВ*) & 1.4 & 580 & 904 & 29,5 \\
\hline
\end{tabular}


Окончание табл. 1

\begin{tabular}{|c|c|c|c|c|c|}
\hline $\begin{array}{c}\text { Материал среднего } \\
\text { клина и характер } \\
\text { армирования }\end{array}$ & $\begin{array}{c}\text { Длина лыжи / } \\
\text { высота колодки, } \\
\text { мм }\end{array}$ & № образца & Macca, $\Gamma$ & $\begin{array}{c}\text { Положение центра } \\
\text { тяжести, мм }\end{array}$ & $\begin{array}{c}\text { Стрела прогиба, } \\
\text { мм }\end{array}$ \\
\hline Гофрокартон & \multirow{4}{*}{$1950 / 29,5$} & 2.1 & 704 & 945 & 29,4 \\
\hline (2 слоя CВ*) & & 2.2 & 704 & 945 & 30,5 \\
\hline \multirow{2}{*}{$\begin{array}{c}\text { Гофрокартон } \\
\left(4 \text { слоя } \mathrm{CB}^{*}\right)\end{array}$} & & 2.3 & 817 & 944 & 25,9 \\
\hline & & 2.4 & 803 & 942 & 26,9 \\
\hline \multirow{2}{*}{$\begin{array}{c}\text { Пенополиуретан } \\
\text { (2 слоя СВ*) }\end{array}$} & \multirow{4}{*}{$1900 / 21,5$} & 3.1 & 506 & 912 & 31,1 \\
\hline & & 3.2 & 510 & 912 & 31,5 \\
\hline \multirow{2}{*}{$\begin{array}{c}\text { Пенополиуретан } \\
(4 \text { слоя СВ*) }\end{array}$} & & 3.3 & 631 & 911 & 34 \\
\hline & & 3.4 & 627 & 911 & 33,1 \\
\hline \multirow{2}{*}{$\begin{array}{c}\text { Пенополиуретан } \\
(4 \text { слоя CВ*) }\end{array}$} & \multirow{4}{*}{$1950 / 29,5$} & 4.1 & 720 & 944 & 26,7 \\
\hline & & 4.2 & 713 & 955 & 24,2 \\
\hline \multirow{2}{*}{$\begin{array}{c}\text { Пенополиуретан } \\
(2 \text { слоя CB*) }\end{array}$} & & 4.3 & 590 & 955 & 31,5 \\
\hline & & 4.4 & 596 & 952 & 26,6 \\
\hline \multirow{2}{*}{$\begin{array}{c}3 \mathrm{~d} \text { печать } \\
(2 \text { слоя УВ*) }\end{array}$} & \multirow{2}{*}{$1900 / 21,5$} & 5.1 & 672 & 907 & 35,4 \\
\hline & & 5.2 & 675 & 910 & 27,9 \\
\hline \multirow{2}{*}{$\begin{array}{c}\text { Древесина низкой } \\
\text { плотности } \\
(2 \text { слоя СВ*, } 2 \text { УВ*) }\end{array}$} & \multirow{6}{*}{$1900 / 21,5$} & 6.1 & 601 & 911 & 28,6 \\
\hline & & 6.2 & 604 & 910 & 29,1 \\
\hline \multirow{2}{*}{$\begin{array}{c}\text { Древесина низкой } \\
\text { плотности } \\
(4 \text { слоя CВ*) }\end{array}$} & & 6.3 & 597 & 910 & 30 \\
\hline & & 6.4 & 595 & 910 & 29,5 \\
\hline \multirow{2}{*}{$\begin{array}{c}\text { Древесина низкой } \\
\text { плотности } \\
(2 \text { слоя СВ*, } 2 \text { УВ*) }\end{array}$} & & 6.5 & 548 & 910 & 27,6 \\
\hline & & 6.6 & 545 & 910 & 27,1 \\
\hline \multirow{2}{*}{$\begin{array}{c}\text { Древесина низкой } \\
\text { плотности } \\
(4 \text { слоя CB*) }\end{array}$} & \multirow{6}{*}{$1950 / 29,5$} & 7.1 & 777 & 952 & 25,8 \\
\hline & & 7.2 & 780 & 950 & 26,2 \\
\hline \multirow{2}{*}{$\begin{array}{l}\text { Древесина низкой } \\
\text { плотности (2 слоя } \\
\left.\text { УВ* }^{*} 2 \text { слоя } \mathrm{CB}^{*}\right)\end{array}$} & & 7.3 & 762 & 945 & 25,4 \\
\hline & & 7.4 & 760 & 945 & 25,8 \\
\hline \multirow{2}{*}{$\begin{array}{l}\text { Древесина низкой } \\
\text { плотности (2 слоя } \\
\text { УВ*, } 2 \text { слоя СВ*) }\end{array}$} & & 7.5 & 680 & 952 & 26,4 \\
\hline & & 7.6 & 675 & 953 & 26,9 \\
\hline \multicolumn{3}{|c|}{ Норма } & & & Не более 30 мм \\
\hline
\end{tabular}

* СВ - стекловолокно, УВ - углеродное волокно.

Испытания проводились нами согласно ГОСТ 30045-93 [14] и разработанной на его основе методике (Лыжа спортивно-беговая. Методики оценки основных эксплуатационных показателей. 01.12.00.000 ПМ1, утверждена 22.07.2019). Определены следующе показатели: масса, стрела прогиба, жесткость средней части, индекс жесткости по Фишеру, длина и высота остаточного прогиба при приложении нормативной нагрузки, разрушающая нагрузка, показатель усталости, жесткость носка и пятки.

Результаты определения длины и высоты остаточного прогиба, жесткости средней части, индекса жесткости по Фишеру приведены в табл. 2, а результаты определения жесткости передней и задней части лыжи приведены в табл. 3. 
Таблица 2

Результаты определения длины и высоты остаточного прогиба, жесткости средней части, индекса жесткости по Фишеру

\begin{tabular}{|c|c|c|c|c|c|c|c|}
\hline $\begin{array}{l}\text { Материал } \\
\text { среднего } \\
\text { клина }\end{array}$ & $\begin{array}{l}\text { Длина лыжи / } \\
\text { высота } \\
\text { колодки, мм }\end{array}$ & $\begin{array}{c}\text { Номер } \\
\text { образца }\end{array}$ & $\begin{array}{l}\text { Жесткость } \\
\text { средней } \\
\text { части, } \\
\text { Н/мм }\end{array}$ & \begin{tabular}{|c|} 
Индекс \\
жесткости \\
по FA \\
(остаточный \\
прогиб \\
0,2 мм), Н \\
\end{tabular} & $\begin{array}{c}\text { Нормативная } \\
\text { нагрузка }\end{array}$ & $\begin{array}{c}\text { Остаточная } \\
\text { длина, мм }\end{array}$ & $\begin{array}{c}\text { Остаточный } \\
\text { прогиб, мм }\end{array}$ \\
\hline \multirow{2}{*}{$\begin{array}{c}\text { Гофрокартон } \\
(4 \text { слоя CB*) }\end{array}$} & \multirow{4}{*}{$1900 / 21,5$} & 1.1 & 98,3 & 310 & 294 & 480 & 0,3 \\
\hline & & 1.2 & 95,7 & 310 & 294 & 475 & 0,3 \\
\hline \multirow{2}{*}{$\begin{array}{c}\text { Гофрокартон } \\
(2 \text { слоя CB*) }\end{array}$} & & 1.3 & 64,8 & 210 & 294 & $-*$ & $-*$ \\
\hline & & 1.4 & 65,6 & 215 & 294 & $-^{*}$ & $-^{*}$ \\
\hline \multirow{2}{*}{$\begin{array}{c}\text { Гофрокартон } \\
(2 \text { слоя CB*) }\end{array}$} & \multirow{4}{*}{$1950 / 29,5$} & 2.1 & 140,5 & 270 & 319 & $-*$ & $-^{*}$ \\
\hline & & 2.2 & 138,2 & 310 & 319 & $-*$ & $-^{*}$ \\
\hline \multirow{2}{*}{$\begin{array}{c}\text { Гофрокартон } \\
(4 \text { слоя СВ*) }\end{array}$} & & 2.3 & 195,7 & 420 & 319 & 660 & 0,9 \\
\hline & & 2.4 & 191,7 & 425 & 319 & 530 & 0,6 \\
\hline \multirow{2}{*}{$\begin{array}{c}\text { Пенополиуретан } \\
(2 \text { слоя CB*) }\end{array}$} & \multirow{4}{*}{$1900 / 21,5$} & 3.1 & 61,2 & 170 & 294 & $-*$ & $-*$ \\
\hline & & 3.2 & 62,3 & 175 & 294 & $-*$ & $-^{*}$ \\
\hline \multirow{2}{*}{$\begin{array}{c}\text { Пенополиуретан } \\
\text { (4 слоя CB*) }\end{array}$} & & 3.3 & 88,1 & 250 & 294 & $-*$ & $-*$ \\
\hline & & 3.4 & 86,2 & 245 & 294 & $-^{*}$ & $-*$ \\
\hline \multirow{2}{*}{$\begin{array}{c}\text { Пенополиуретан } \\
(4 \text { слоя CB*) }\end{array}$} & \multirow{4}{*}{$1950 / 29,5$} & 4.1 & 141,5 & 320 & 319 & 520 & 0,2 \\
\hline & & 4.2 & 194,3 & 420 & 319 & 640 & 0,95 \\
\hline \multirow{2}{*}{$\begin{array}{c}\text { Пенополиуретан } \\
(2 \text { слоя CB*) }\end{array}$} & & 4.3 & 128,8 & 370 & 319 & 560 & 0,46 \\
\hline & & 4.4 & 144,4 & 310 & 319 & $-*$ & $-^{*}$ \\
\hline \multirow{2}{*}{$\begin{array}{c}\text { 3d печать } \\
(2 \text { слоя УВ } *)\end{array}$} & \multirow{2}{*}{$1900 / 21,5$} & 5.1 & 62,7 & 210 & 294 & $-^{*}$ & $-^{*}$ \\
\hline & & 5.2 & 61,4 & 190 & 294 & $-*$ & $-*$ \\
\hline \multirow{2}{*}{$\begin{array}{c}\text { Древесина } \\
\text { низкой плот- } \\
\text { ности (2 слоя } \\
\mathrm{CB}^{*}, 2 \text { УВ*) } \\
\end{array}$} & \multirow{6}{*}{$1900 / 21,5$} & 6.1 & 123,2 & 420 & 294 & 495 & 0,8 \\
\hline & & 6.2 & 122,1 & 423 & 294 & 490 & 0,85 \\
\hline Древесина & & 6.3 & 89 & 305 & 294 & 480 & 0,3 \\
\hline $\begin{array}{c}\text { низкой } \\
\text { плотности } \\
\left(4 \text { слоя } \mathrm{CB}^{*}\right)\end{array}$ & & 6.4 & 94,2 & 310 & 294 & 480 & 0,4 \\
\hline \multirow{2}{*}{$\begin{array}{c}\text { Древесина } \\
\text { низкой } \\
\text { плотности } \\
(2 \text { слоя СВ*, } \\
2 \text { УВ*) }\end{array}$} & & 6.5 & 124,2 & 415 & 294 & 490 & 0,9 \\
\hline & & 6.6 & 123,9 & 418 & 294 & 490 & 0,8 \\
\hline \multirow{2}{*}{$\begin{array}{c}\text { Древесина } \\
\text { низкой } \\
\text { плотности } \\
\left(4 \text { слоя CВ }{ }^{*}\right)\end{array}$} & \multirow{6}{*}{$1950 / 29,5$} & 7.1 & 223,1 & 470 & 319 & 730 & 1,1 \\
\hline & & 7.2 & 228,3 & 475 & 319 & 725 & 1,1 \\
\hline $\begin{array}{l}\text { Древесина } \\
\text { низкой }\end{array}$ & & 7.3 & 267,5 & 630 & 319 & 795 & 1,7 \\
\hline $\begin{array}{c}\text { плотности } \\
(2 \text { слоя УВ*, } \\
2 \text { слоя СВ } \text { CB }^{*}\end{array}$ & & 7.4 & 261,4 & 620 & 319 & 790 & 1,7 \\
\hline \multirow{2}{*}{$\begin{array}{c}\text { Древесина } \\
\text { низкой плот- } \\
\text { ности (2 слоя } \\
\text { УВ*, } 2 \text { слоя } \\
\left.\mathrm{CB}^{*}\right) \\
\end{array}$} & & 7.5 & 211,3 & 560 & 319 & 610 & 1,35 \\
\hline & & 7.6 & 210,1 & 570 & 319 & 610 & 1,4 \\
\hline & Норма & & - & Не менее 50 & - & $350-550 \mathrm{MM}$ & $0,6-1,7 \mathrm{MM}$ \\
\hline
\end{tabular}

* Индекс жесткости по Фишеру меньше нормативной нагрузки. 
Результаты определения жесткости передней и задней части лыжи

Таблица 3

\begin{tabular}{|c|c|c|c|c|c|c|}
\hline \multirow{2}{*}{$\begin{array}{c}\text { Материал } \\
\text { среднего клина } \\
\text { и характер } \\
\text { армирования }\end{array}$} & \multirow[b]{2}{*}{$\begin{array}{c}\text { Длина лыжи / } \\
\text { высота } \\
\text { колодки, мм }\end{array}$} & \multirow[b]{2}{*}{$\begin{array}{l}\text { Номер } \\
\text { образца }\end{array}$} & \multicolumn{2}{|c|}{$\begin{array}{c}\text { Испытание на жесткость } \\
\text { передней части лыжи }\end{array}$} & \multicolumn{2}{|c|}{$\begin{array}{c}\text { Испытание на жесткость } \\
\text { задней части лыжи }\end{array}$} \\
\hline & & & $\begin{array}{c}\text { Нагрузка } \\
\text { при } \\
\text { прогибе } \\
30 \text { мм, Н }\end{array}$ & $\begin{array}{c}\text { Жесткость } \\
\text { передней } \\
\text { части, Н/мм }\end{array}$ & $\begin{array}{c}\text { Нагрузка при } \\
\text { прогибе } \\
30 \text { мм, Н }\end{array}$ & $\begin{array}{c}\text { Жесткость } \\
\text { задней части, } \\
\text { Н/мм }\end{array}$ \\
\hline \multirow{2}{*}{$\begin{array}{l}\text { Гофрокартон } \\
\left(4 \text { слоя } \mathrm{CB}^{*}\right) \\
\end{array}$} & \multirow{4}{*}{$1900 / 21,5$} & 1.1 & 61 & 2,03 & 41 & 1,37 \\
\hline & & 1.2 & 60 & 2,00 & 43 & 1,43 \\
\hline \multirow{2}{*}{$\begin{array}{l}\text { Гофрокартон } \\
(2 \text { слоя CB*) }\end{array}$} & & 1.3 & 44 & 1,47 & 32 & 1,07 \\
\hline & & 1.4 & 42 & 1,40 & 33 & 1,10 \\
\hline \multirow{2}{*}{$\begin{array}{l}\text { Гофрокартон } \\
\left(2 \text { слоя } \mathrm{CB}^{*}\right)\end{array}$} & \multirow{4}{*}{$1950 / 29,5$} & 2.1 & 67 & 2,23 & 34 & 1,13 \\
\hline & & 2.2 & 63 & 2,1 & 29 & 0,97 \\
\hline \multirow{2}{*}{$\begin{array}{c}\text { Гофрокартон } \\
\left(4 \text { слоя } \mathrm{CB}^{*}\right)\end{array}$} & & 2.3 & 86 & 2,87 & 33 & 1,1 \\
\hline & & 2.4 & 79 & 2,63 & 33 & 1,1 \\
\hline \multirow{2}{*}{$\begin{array}{l}\text { Пенополиуретан } \\
\left(2 \text { слоя } \mathrm{CB}^{*}\right)\end{array}$} & \multirow{4}{*}{$1900 / 21,5$} & 3.1 & 38 & 1,27 & 28 & 0,93 \\
\hline & & 3.2 & 41 & 1,37 & 30 & 1,00 \\
\hline \multirow{2}{*}{$\begin{array}{l}\text { Пенополиуретан } \\
\text { (4 слоя СВ) }\end{array}$} & & 3.3 & 62 & 2,07 & 50 & 1,67 \\
\hline & & 3.4 & 59 & 1,97 & 52 & 1,73 \\
\hline \multirow{2}{*}{$\begin{array}{l}\text { Пенополиуретан } \\
\left(4 \text { слоя } \mathrm{CB}^{*}\right)\end{array}$} & \multirow{4}{*}{$1950 / 29,5$} & 4.1 & 53 & 1,77 & 35 & 1,17 \\
\hline & & 4.2 & 74 & 2,47 & 33 & 1,1 \\
\hline \multirow{2}{*}{$\begin{array}{c}\text { Пенополиуретан } \\
(2 \text { слоя CB*) }\end{array}$} & & 4.3 & 49 & 1,63 & 28 & 0,93 \\
\hline & & 4.4 & 58 & 1,93 & 34 & 1,13 \\
\hline \multirow{2}{*}{$\begin{array}{c}\text { 3d печать } \\
(2 \text { слоя УВ*) }\end{array}$} & \multirow{2}{*}{$1900 / 21,5$} & 5.1 & 46 & 1,53 & 42 & 1,4 \\
\hline & & 5.2 & 51 & 1,7 & 42 & 1,4 \\
\hline \multirow{2}{*}{ 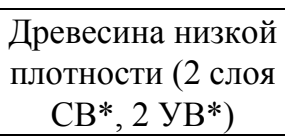 } & \multirow{6}{*}{$1900 / 21,5$} & 6.1 & 59 & 1,97 & 51 & 1,7 \\
\hline & & 6.2 & 62 & 2,07 & 53 & 1,76 \\
\hline \multirow{2}{*}{$\begin{array}{c}\text { Древесина низкой } \\
\text { плотности } \\
\left(4 \text { слоя } \mathrm{CB}^{*}\right)\end{array}$} & & 6.3 & 60 & 2 & 52 & 1,73 \\
\hline & & 6.4 & 61 & 2,03 & 51 & 1,70 \\
\hline \multirow{2}{*}{$\begin{array}{c}\text { Древесина низкой } \\
\text { плотности (2 слоя } \\
\text { CВ*, } 2 \text { УВ*) }^{*}\end{array}$} & & 6.5 & 59 & 1,97 & 52 & 1,73 \\
\hline & & 6.6 & 58 & 1,93 & 55 & 1,83 \\
\hline \multirow{2}{*}{$\begin{array}{c}\text { Древесина низкой } \\
\text { плотности } \\
\text { (4 слоя СВ) } \\
\end{array}$} & \multirow{6}{*}{$1950 / 29,5$} & 7.1 & 75 & 2,5 & 26 & 0,87 \\
\hline & & 7.2 & 71 & 2,37 & 30 & 1,00 \\
\hline \multirow{2}{*}{ 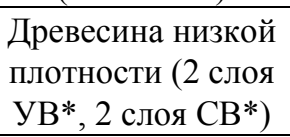 } & & 7.3 & 84 & 2,8 & 32 & 1,07 \\
\hline & & 7.4 & 80 & 2,67 & 35 & 1,17 \\
\hline \multirow{2}{*}{$\begin{array}{l}\text { Древесина низкой } \\
\text { плотности (2 слоя } \\
\text { УВ*, } 2 \text { слоя СВ*) }\end{array}$} & & 7.5 & 62 & 2,07 & 32 & 1,07 \\
\hline & & 7.6 & 61 & 2,03 & 31 & 1,03 \\
\hline \multicolumn{3}{|c|}{ Норма } & $40-60$ & $1,33-2,00$ & $50-80$ & $1,66-2,66$ \\
\hline
\end{tabular}

* СВ - стекловолокно, УВ - углеродное волокно.

Жесткость передней части лыж у ряда исследованных образцов была завышена, но исходя из опыта эксплуатации лыж спортсменами, можно сделать вывод, что она может быть больше, чем прописано в стандарте. Значение показателя жесткости в задней части лыжи в большинстве случаев получилось меньше нормативных значений, исправить ситуацию можно введением дополнительного слоя армирования в задней части лыжи. 
Результаты определения разрушающей нагрузки

\begin{tabular}{|l|c|c|c|}
\hline \multicolumn{1}{|c|}{ Материал } & $\begin{array}{c}\text { Длина лыжи / высота } \\
\text { колодки, мм }\end{array}$ & Номер образца & $\begin{array}{c}\text { Разрушающая } \\
\text { нагрузка, Н }\end{array}$ \\
\hline Гофрокартон & $1900 / 21,5$ & 1.1 & $\mathbf{2 4 1 6}$ \\
\hline Гофрокартон & $1950 / 29,5$ & 2.3 & $\mathbf{3 0 7 5}$ \\
\hline Пенополиуретан & $1950 / 29,5$ & 4.1 & 1314 \\
\hline Древесина низкой плотности & $1900 / 21,5$ & 6.5 & $\mathbf{2 4 5 8}$ \\
\hline \multicolumn{2}{|r|}{ Норма } & Не менее $2354 \mathrm{H}$ \\
\hline
\end{tabular}

Анализ полученных в результате испытаний данных по определению эксплуатационных показателей качества лыж дал возможность определить, что наилучшие показатели были у лыж с клиньями из древесины низкой плотности, в частности, удалось достигнуть показателей массы ниже 550 г у образцов 6.5 и 6.6.

В результате анализа полученных значений эксплуатационных показателей было отобрано несколько образцов для испытаний по определению разрушающей нагрузки. Результаты проведенных испытаний были представлены в табл. 4. Из табл. 4 видно, что нормативным показателям удовлетворяют лыжи с клиньями из древесины низкой плотности и гофрокартона соответствуют нормативному значению.

Таким образом, для испытаний по определению показателя усталости при циклическом нагружении был отобран образец из древесины низкой плотности с колодкой 29,5 мм, показатель усталости которого составил 6,7\% (при норме не более 60\%), выдержав 50000 циклов нагружения.

Заключение. В результате работы был проведен анализ материалов, применяемых в современных конструкциях лыж, с целью снижения показателя их массы. На основании этого анализа были подобраны материалы для практической апробации. А именно пенополиуретан, гофрокартон, материал модельный для 3d-печати, древесина низкой плотности. В производственных условиях были изготовлены лыжи, ко- торые далее были испытаны. В результате исследований установлено, что наиболее преспективным материалом для клина является древесина низкой плотности, так как масса лыжи, изготовленной на ее основе, помимо достижения необходимых эксплуатационных показателей, составляет менее 550 г, что позволит снизить массу пары лыж до 1100 г. Помимо этого, применение данного материала не требуют закупки нового оборудования, технологический процесс практически полностью идентичен тому, который реализован в филиале «Телеханы» государственного предприятия «Беларусьторг».

Также перспективным является гофрокартон. Клинья, изготовленные на его основе, имеют высокие показатели прочности, сопротивления разрушающей нагрузке, но использование фанеры в качестве боковых поверхностей клиньев нецелесообразно, так как из-за перпендикулярно расположенных слоев шпона фанера плохо поддается воздействию изгибающих нагрузок, которые испытывает лыжа во время склеивания, что приводит к растрескиванию боковых поверхностей.

Таким образом, конструкция облегченных лыж будет отличаться от конструкции обычных лыж для массового потребителя только применяемыми материалами (древесина низкой плотности для среднего клина, углеродное волокно для армирующего слоя) и состоять из скользящего, армирующего, склеивающего, верхнего декоративного слоев и среднего клина.

\section{Список литературы}

1. StudFiles / Сотовые заполнители. URL: https://studfile.net/preview/8869591/page:28/ (дата обращения: 12.03.2021).

2. oDveryah.ru / Что такое сотовый наполнитель URL: https://odveryah.ru/montazh/sotovyjnapolnitel-dlya-dverej (дата обращения: 12.03.2021).

3. Гиясов Б. И., Серегин Н. Г., Серегин Д. Н. Трёхслойные панели из полимерных композиционных материалов: учеб. пособие. М.: Изд-во АСВ, 2015. 64 с.

4. Carbon Studio / Алюминиевые и термопластиковые соты, слоистые материалы, многослойные панели. URL: https://tech.carbonstudio.ru/product/sfera-struktur/alyuminievye-soty (дата обращения: 13.03.2021).

5. Механическая обработка древесины. Перспективы развития производства лыж в стране: обзор информации по материалам Всесоюзного научно-технического совещания. М.: ВНИПИЭИлеспром, 1985. $52 \mathrm{c.}$

6. Арамидная ткань / Описание состава, свойств, сфера применения. URL: https://mattrasik.ru/protkani/iskusstvennye/aramidnaya-tkan-opisanie-sostava-svojstv-sfer-primeneniya/ (дата обращения: 18.03.2021). 
7. Арамидное волокно / Арамидное волокно и арамидопластики. URL: https://moodle.kstu.ru/ pluginfile.php/339288/mod resource/content/1/1.pdf (дата обращения: 18.03.2021).

8. Carbon Studio / Арамидные соты для авиации nomex. URL: https://carbonstudio.ru/item/aviacionnye-sort-nomex (дата обращения: 18.03.2021).

9. КОНТУР ПАК / Гофрированный картон - виды и применение. URL: https://www.korobok.ru/katalog_fefco/stati/gofrirovannyj_karton_vidy_i_primenenie/(дата обращения: 19.03.2021).

10. ГофроЛайн / Характеристики гофрокартона, классификации, типы гофрокартона. URL: https://www.gofroline.ru/poleznoe/harakteristiki-gofrokartona.html (дата обращения: 19.03.2021).

11. PackPro / Bсё о гофрокартоне: характеристика, виды, классы. URL: https://packpro.by/info/articles/vsye-o-gofrokartone/ (дата обращения: 19.03.2021).

12. Антек / Гофрокартон (гофрированный картон). Статья. URL: https://www.antech.ru/wiki/stati/ gofrokarton/ (дата обращения: 19.03.2021).

13. Harris J. C., Rumack B. H., Aldrich F. D. Toxicology of urea formaldehyde and polyurethane foam insulation. J Am Med Assoc 1981; 245 (3).

14. Лыжи спортивно-беговые. Методы испытаний: ГОСТ 30045-93. Введ. 01.01.1995. М.: Изд-во стандартов, 1994. 15 с.

\section{References}

1. StudFiles. Sotovyye zapolniteli [StudFiles. Honeycomb placeholders]. Available at: https://studfile.net/preview/8869591/page:28/ (accessed 12.03.2020).

2. Chto takoye sotovyy napolnitel' [What is honeycomb filler]. Available at: https://odveryah.ru/montazh/sotovyj-napolnitel-dlya-dverej (accessed 12.03.2020).

3. Giyasov B. I., Seregin N. G., Seregin D. N. Trekhsloynyye paneli iz polimernykh kompozitsionnykh materialov: uchebnoye posobiye [Three-layer panels made of polymer composite materials: a tutorial]. Moscow: ASV Publ., 2015. 64 p.

4. Alyuminiyevye i termoplastikovyye soty, sloistyye materialy, mnogoslojynyye paneli [CarbonStudio. Aluminum and thermoplastic honeycombs, laminates, sandwich panels]. Available at: https://tech.carbonstudio.ru/product/sfera-struktur/alyuminievye-soty (accessed 13.03.2020).

5. Mekhanicheskaya obrabotka drevesiny. Perspektivy razvitiya proizvodstva lyzh $v$ strane: obzor informatsii po materialam Vsesoyuznogo nauchno-tekhnicheskogo soveshchaniya [Overview of information on the materials of the All-Union Scientific and Technical Meeting]. Moscow, 1985. 52 p. (In Russian).

6. Aramidnaya tkan'. Opisaniye sostava, svoystv, sfera primeneniya [Aramid fabric. Description of the composition, properties, scope]. Available at: https://mattrasik.ru/pro-tkani/iskusstvennye/aramidnaya-tkanopisanie-sostava-svojstv-sfer-primeneniya/ (accessed 18.03.2020).

7. Aramidnoye volokno i aramidoplastiki [Aramid fiber and aramidoplastics]. Available at: https://moodle.kstu.ru/pluginfile.php/339288/mod_resource/content/1/1.pdf (accessed 18.03.2020)

8. Aramidnyye soty dlya aviatsii nomex [Aramid honeycomb for aviation nomex]. Available at: https://carbonstudio.ru/item/aviacionnye-sort-nomex (accessed 18.03.2020).

9. Gofrirovannyy karton - vidy i primeneniye [Corrugated cardboard - types and applications]. Available at: https://www.korobok.ru/katalog_fefco/stati/gofrirovannyj_karton_vidy_i_primenenie/ (accessed 19.03.2020).

10. Kharakteristiki gofrokartona, klassifikatsii, tipy gofrokartona [Corrugated board characteristics, classifications, types of corrugated board]. Available at: https://www.gofroline.ru/poleznoe/harakteristikigofrokartona.html (accessed 19.03.2020).

11. Vse o gofrokartone: kharakteristika, vidy, klassy [Everything about corrugated board: characteristics, types, classes]. Available at: https://packpro.by/info/articles/vsye-o-gofrokartone/ (accessed 19.03.2020).

12. Gofrokarton (gofrirovannyy karton) [Corrugated cardboard (corrugated cardboard)]. Available at: https://www.antech.ru/wiki/stati/gofrokarton/ (accessed 19.03.2020).

13. Harris J. C., Rumack B. H., Aldrich F. D. Toxicology of urea formaldehyde and polyurethane foam insulation. J Am Med Assoc 1981; 245 (3).

14. GOST 30045-93. Lyzhi sportivno-begovyye. Metody ispytaniy [Cross-country skiing. Test methods]. Moscow, Izdatel'stvo standartov Publ., 1994. 15 p. (In Russian).

\section{Информация об авторах}

Полховский Антон Викторович - магистр технических наук, аспирант кафедры технологии и дизайна изделий из древесины. Белорусский государственный технологический университет (220006, г. Минск, ул. Свердлова, 13а, Республика Беларусь). E-mail: antopolx1@mail.ru 
Прохорчик Сергей Александрович - кандидат технических наук, доцент, декан факультета заочного образования. Белорусский государственный технологический университет (220006, г. Минск, ул. Свердлова, 13a, Республика Беларусь). E-mail: prohor@tut.by

Шетько Сергей Васильевич - кандидат технических наук, доцент, проректор по научной работе. Белорусский государственный технологический университет (220006, г. Минск, ул. Свердлова, 13a, Республика Беларусь). E-mail: shs@belstu.by

Ручкина Елена Васильевна - ассистент кафедры технологии и дизайна изделий из древесины. Белорусский государственный технологический университет (220006, г. Минск, ул. Свердлова, 13a, Республика Беларусь).

\section{Information about of authors}

Polkhovsky Anton Viktorovich - Master of Engineering, PhD student, the Department of Technology and Design of Wood Products. Belarusian State Technological University (13a, Sverdlova str., 220006, Minsk, Republic of Belarus). E-mail: antopolx1@mail.ru

Prokhorchik Sergey Aleksandrovich - PhD (Engineering), Associate Professor, Dean of the Faculty of Distance Education. Belarusian State Technological University (13a, Sverdlova str., 220006, Minsk, Republic of Belarus). E-mail: prohor@tut.by

Shet'ko Sergey Vasil'yevich - PhD (Engineering), Associate Professor, Vice-rector for Research. Belarusian State Technological University (13a, Sverdlova str., 220006, Minsk, Republic of Belarus). E-mail: shs@belstu.by

Ruchkina Elena Vasil'yevna - Assistant, the Department of Technology and Design of wood Products. Belarusian State Technological University (13a, Sverdlova str., Minsk, 220006, Republic of Belarus). 